Wilson Bull., I 15(3), 2003, pp. 277-284

\title{
PATTERNS OF COWBIRD PARASITISM IN THE SOUTHERN ATLANTIC COASTAL PLAIN AND PIEDMONT
}

\author{
JOHN C. KILGO ${ }^{1,3}$ AND CHRISTOPHER E. MOORMAN²
}

\begin{abstract}
Until recently, little information was available on patterns of brood parasitism by Brownheaded Cowbirds (Molothrus ater) in the southeastern United States, a region into which cowbirds expanded their range only during the last half of the Twentieth Century and where their abundance is relatively low. We compiled parasitism data from several published and unpublished studies conducted in Georgia and South Carolina from 1993-2000 to examine levels of brood parasitism and determine frequent host species. The combined dataset included 1,372 nests of 24 species reported in the literature to have been parasitized by cowbirds. The parasitism rate on all species combined was $8.2 \%$. Considering only those species that served as hosts in these studies $(n=12)$, the parasitism rate was 9.3\%. Seven species were parasitized at rates $\geq 10 \%$. Based on the extent of parasitism (among studies and locations), their relative abundance, and the sample size of nests, Prairie Warblers (Dendroica discolor), Hooded Warblers ( Wilsonia citrina), Yellow-breasted Chats (Icteria virens), and Indigo Buntings (Passerina cyanea), all shrub nesters, appear to be the most important cowbird hosts in the region. Parasitism on some species reported as frequent hosts elsewhere was extremely low or not documented. We conclude that the impact of brood parasitism on the seasonal fecundity of hosts in the region probably is minimal, but additional work is warranted on species of concern, such as the Painted Bunting (Passerina ciris). Received 3 April 2003, accepted 26 July 2003.
\end{abstract}

Brood parasitism by Brown-headed Cowbirds (Molothrus ater) has been studied intensively in many parts of their range, particularly near the center of their historical range in the midwestern United States (Lowther 1993). Levels of cowbird parasitism vary markedly according to region (Hoover and Brittingham 1993), landscape (Robinson et al. 1995), and habitat (Brittingham and Temple 1996, Burhans 1997). For example, parasitism rates on Wood Thrushes (Hylocichla mustelina) range as high as $100 \%$ in some Midwestern host populations (Robinson et al. 1995), but rates can be $<10 \%$ within the same region and in northeastern populations (Roth et al. 1996). Parasitism typically results in a reduction in the number of host young fledged per nesting attempt, but the effect of various levels of parasitism on seasonal productivity of hosts is less clear (Pease and Grzybowski 1995). Although recent evidence suggests that the impacts of parasitism on seasonal fecundity may be minimal in some situations (Schmidt and Whelan 1999, Whitehead et al. 2000), cowbirds still are widely considered a

U.S. Forest Service Savannah River, Southern Research Station, P.O. Box 700, New Ellenton, SC 29809, USA.

2 Dept. of Forestry, Box 8003, North Carolina State Univ., Raleigh, NC 27695. USA.

3 Corresponding author; e-mail: jkilgo@fs.fed.us negative influence on those host species that are declining.

The Brown-headed Cowbird colonized the southeastern United States during the first half of the Twentieth Century and did not reach the southeastern Coastal Plain until after 1957 (Cruz et al. 2000). Although the species increased in the southeastern Coastal Plain between 1970 and 1988 (Wiedenfeld 2000), it declined from 1988-2002 in the three southeastern Breeding Bird Survey (BBS) regions (Southern Piedmont, Upper Coastal Plain, and Coastal Flatwoods; Sauer et al. 2003). Cowbird abundance throughout most of Georgia and South Carolina currently is low relative to the rest of the species' range; during the period 1982-1996, a mean of 4-1 0 birds were detected per BBS route compared to 1 I-100 birds throughout most of the Midwest and Great Plains and $>100$ in the area of greatest abundance in North Dakota (Sauer et al. 2003). Cowbird abundance in the southeastern United States probably is limited by landscape structure, as the region is among the most heavily forested in the eastern United States, with $65-74 \%$ of the land area classified as timberland (Trani et al. 2001).

In spite of the Brown-headed Cowbird's increase in population size and range expansion into this area of naive hosts, until recently there has been little information published on cowbird parasitism patterns in the Southeast, 
TABLE 1. Number of nests of species that regularly host Brown-headed Cowbirds (range-wide) and number of species represented from studies reporting parasitism at each of four study sites in Georgia and South Carolina, $1993-2000$.

\begin{tabular}{|c|c|c|c|}
\hline Location & $\begin{array}{l}\text { Number } \\
\text { of nests }\end{array}$ & Species. & Siudy \\
\hline $\begin{array}{l}\text { Fort Benning Military Reser- } \\
\text { vation }\end{array}$ & 266 & 7 & Howell ( 1998) \\
\hline $\begin{array}{l}\text { Piedmont National Wildlife } \\
\text { Refuge }\end{array}$ & 474 & 20 & $\begin{array}{l}\text { Brunjes (1998), Raftovitch (1998), Lang (1998), } \\
\text { White et al. (1999), 1.. A. Powell (unpubl. data) }\end{array}$ \\
\hline Savannah River Site & 411 & 21 & $\begin{array}{l}\text { Sargent et al. (1997, 2003, unpubl. data), Moorman } \\
\text { (1999. unpubl. data), Moorman et al. (2002), Kre- } \\
\text { mentz and Powell (2000), Stober and Krementz } \\
(2000) \text {, F! J. Champlin and JCK (unpubl. data) }\end{array}$ \\
\hline Island & 261 & 6 & Whitehead et al. (2000) \\
\hline
\end{tabular}

perhaps in part because of the low relative abundance of cowbirds in the region. Nevertheless, considerable interest exists among land managers and researchers as to the risks posed by cowbird parasitism to songbird populations. To examine levels and patterns of cowbird parasitism in the southern Atlantic Coastal Plain and adjacent Piedmont, we present data compiled from unpublished and recently published songbird nesting studies conducted during the 1990s and 2000 at four locations in Georgia and South Carolina.

\section{STUDY AREAS AND METHODS}

We compiled data from published and unpublished studies (Table 1) conducted at four locations across the Piedmont and southern Atlantic Coastal Plain physiographic provinces in Georgia and South Carolina:

Fort Benning Military Reservation.-Howell (1998) monitored nests from 1995-1996 at Fort Benning (32' 39' N, 84 $82^{\circ}$ ' W), located on the Fall Line dividing the Piedmont and Coastal Plain physiographic provinces in western Georgia. Approximately $65 \%$ of the site is pine (Pinus spp.) forest, with the remainder in mixed pine-hardwood and bottomland hardwood forests. Study sites were in 26to 104-year-old pine forests managed for Redcockaded Woodpeckers (Picoides borealis; Howell 1998).

Piedmont National Wildlife Refuge.-Several workers (Brunjes 1998, Lang 1998, Raftovitch 1998, White et al. 1999, L. A. Powell unpubl. data) monitored nests from 19931997 at Piedmont NWR (33" 1 1' N, 83" 77' $\mathrm{W})$ in the Piedmont physiographic province of central Georgia. The site is dominated by pine and mixed pine-hardwood forest, with pure hardwood forests confined to small drainages (Brunjes 1998). Study sites were in pine and mixed pine-hardwood forests $\geq 60$ years old.

Savannah River Site.-Several workers (Sargent et al. 1997, 2003, unpubl. data; Moorman 1999, unpubl. data; Krementz and Powell 2000; Stober and Krementz 2000; Moorman et al. 2002; I? J. Champlin and JCK unpubl. data) monitored nests from 19932000 at the Savannah River Site (33" 28' N, 81 " 67 ' W). This site is a U.S. Dept. of Energy National Environmental Research Park in the Upper Coastal Plain physiographic province in western South Carolina. Approximately $62 \%$ of the site is $<\%$ )-year-old pine forest, $20 \%$ is 50 - to loo-year-old bottomland hardwood forest, and the remainder is 50 - to 100 year-old upland hardwood and mixed pinehardwood forest. Approximately $10 \%$ was in $<1$ O-year-old pine plantation (Blake in press).

James Island, South Carolina -Whitehead et al. (2000) monitored nests from 1997-1 998 at James island (32" 73' N, 79" 96' W), a coastal barrier island near Charleston, South Carolina. Study sites were old fields composed of 4- to g-year-old successional vegetation. Fields were surrounded by mixed pinehardwood forest (Whitehead et al. 2000).

The landscape composition and context of the study sites, which were more forested than the areas surrounding them, may have biased the observed parasitism rates slightly downward relative to the region. However, we believe the reported parasitism rates are approximatcly representative of the region as a whole 
for the following reasons. First, the landscape of Georgia and South Carolina is primarily forested (Trani et al. 2001). Second, all study sites were accessible to cowbirds; one entire site (James Island) and portions of the remaining three were within the commuting range of cowbirds from high quality foraging areas $(7 \mathrm{~km}$; Rothstein et al. 1984, Thompson 1994), and cowbirds were observed throughout each site (J. H. Brunjes pers. comm., M. A. Howell pers. comm., JCK pers. obs., M. A. Whitehead pers. comm.). Finally, one of the sites, James Island, was in a landscape predominantly fragmented by suburban development.

During all studies nests were located and nesting success was monitored according to standard protocols (Martin and Geupel 1993). Here, we consider only those species that regularly host cowbirds (Friedmann 1963, Friedmann and Kiff 1985). We identify frequent hosts as those with regional parasitism rates $\geq 10 \%$.

\section{RESULTS AND DISCUSSION}

The combined dataset included 1,372 nests of 24 species (Table 1). Each study site was represented by at least 260 nests of potential host species. Additional nest data existed among the reported studies for several species known to have hosted cowbirds (Friedmann 1963, Friedmann and Kiff 1985), but which are either seldom parasitized or reject cowbird eggs when parasitized (i.e., they rarely raise cowbird young successfully). These included Mourning Doves (Zenaida macroura, $n=4$ ), Yellow-billed Cuckoos (Coccyzus american$u s, n=18$ ), Northern Mockingbirds (Mimus polyglottos, $n=2$ ), and Brown Thrashers (Toxostoma rufum, $n=16$ ). None of these were parasitized in the reported studies.

Of the 1,372 nests, only $113(8.2 \%)$ were parasitized, and of the 24 potential hosts, only 12 actually served as hosts (Table 2). The parasitism rate on 1,2 12 nests of actual hosts was $9.3 \%$. Seven species were frequent hosts (total parasitism rates $\geq 10 \%$ ): White-eyed Vireos (Vireo griseus), Prairie Warblers (Dendroica discolor), Hooded Warblers (Wilsonia citrina), Yellow-breasted Chats (Icteria virens), Indigo Buntings (Passerina cyanea), Painted Buntings ( $P$. ciris), and Blue Grosbeaks (Guiraca caerulea). Among these species, the mean parasitism rate was $18.2 \%$. Considering the extent of parasitism (among studies and locations), the abundance of the hosts, and sample sizes of nests, Prairie Warblers, Hooded Warblers, Yellow-breasted Chats, and Indigo Buntings appeared to be the most important cowbird hosts in the region. The mean parasitism rate on these species was $15.8 \%$.

The suite of species parasitized most frequently differed sounhat from that reported by Friedmann (1963; see also Lowther 1993) for the entire range of the cowbird, and from Potter and Whitehurst (198 1) for the Carolinas. Only two (Yellow-breasted Chats and Indigo Buntings) of the seven frequent hosts reported here are among the 17 most frequent cowbird hosts range-wide (Friedmann 1963), despite several of those species being well represented in our sample. In contrast, Whiteeyed Vireos, Prairie Warblers, and Hooded Warblers were frequent hosts in Georgia and South Carolina, but are not among the 17 listed by Friedmann (1963), though all three are well-known cowbird hosts (Hopp et al. 1995, Nolan 1978, Evans Ogden and Stutchbury 1994, respectively). Species that frequently host cowbirds elsewhere (Lowther 1993, Roth et al. 1996) but rarely did in these studies included Wood Thrushes (2 of 169), Ovenbirds (0 of 1 I), Kentucky Warblers (Oporornis formosus; 0 of 33), and Eastern Towhees (Pipilo erythrophthalmus; 4 of 109; Table 2). Potter and Whitehurst ( 198 1) reported that Eastern Towhees were the most frequent host and Wood Thrushes were the fourth most frequent host in the Carolinas. These authors reported only single observations of parasitism each for White-eyed Vireos, Prairie Warblers, Yellow-breasted Chats, Indigo Buntings, and Painted Buntings, and no observations for Hooded Warblers. However, their data consisted primarily of observations of adults feeding fledglings in backyard habitats, where Eastern Towhees and Wood Thrushes may be more likely to appear than the frequent hosts.

All seven frequent hosts arc understory nesters, with six (White-eyed Vireos, Prairie Warblers, Yellow-breasted Chats, Indigo Buntings, Painted Buntings, and Blue Grosbeaks) using shrub-scrub habitats and one (Hooded Warblers) using bottomland hardwood forests. Although canopy-nesting species generally were under represented in the sample, ground 
TABLE 2. Rates of brood parasitism by Brown-headed Cowbirds in Georgia (Piedmont National Wildlife Refuge, PNWR; Fort Benning Military Reservation, FBMR) and South Carolina (Savannah River Site, SRS; James Island, JISC) from 1993-2000. All species listed are known cowbird hosts (Friedmann 1963, Friedmann and Kiff 1985).

\begin{tabular}{|c|c|c|c|c|c|c|}
\hline Species & Site & $\begin{array}{c}\text { Relative } \\
\text { abundance }\end{array}$ & $\begin{array}{l}\text { Number } \\
\text { of nests }\end{array}$ & $\begin{array}{c}\text { Number } \\
\text { parasitized }\end{array}$ & Percent & Source \\
\hline \multirow[t]{2}{*}{$\begin{array}{l}\text { Acadian Flycatcher (Empi- } \\
\text { donax virescens) }\end{array}$} & SRS & $\mathrm{C}$ & 3 & 0 & 0 & $\begin{array}{l}\text { Moorman (1999), R. A. } \\
\text { Sargent et al. (unpubl.) }\end{array}$ \\
\hline & PNWR & $\mathrm{U}$ & 1 & 0 & 0 & $\begin{array}{l}\text { Brunjes (1998), Raf'tovitch } \\
\text { ( 1998) }\end{array}$ \\
\hline Total & & & 4 & 0 & 0 & \\
\hline \multirow[t]{2}{*}{$\begin{array}{l}\text { White-eyed } \\
\text { seus })\end{array}$} & PNWR & $\mathrm{C}$ & 2 & 0 & 0 & $\begin{array}{l}\text { Brunjes (1998), Raftovitch } \\
(199 \mathrm{X})\end{array}$ \\
\hline & SRS & $\mathrm{C}$ & 18 & 2 & 11.1 & $\begin{array}{l}\text { Moorman (1999), R. A. } \\
\text { Sargent et al. (unpubl.) }\end{array}$ \\
\hline Total & & & 20 & 2 & 10.0 & \\
\hline $\begin{array}{c}\text { Blue-headed Vireo (Vireo so- } \\
\text { litarius) }\end{array}$ & PNWR & $\mathrm{R}$ & 7 & 0 & 0 & $\begin{array}{l}\text { Brunjes ( 1998), Raf'tovitch } \\
\text { (1998) }\end{array}$ \\
\hline $\begin{array}{l}\text { Red-eyed Vireo (Vireo oliva- } \\
\text { ceous) }\end{array}$ & PNWR & $\mathrm{C}$ & 5 & 0 & 0 & $\begin{array}{l}\text { Brunjes (1998) } \\
(1998)\end{array}$ \\
\hline \multirow[t]{2}{*}{$\begin{array}{l}\text { Carolina Wren (Thryothorus } \\
\text { ludovicianus) }\end{array}$} & PNWR & $\mathrm{V}$ & 1 & 0 & 0 & $\underset{(1998)}{\text { Brunjes }}(1998)$, Raftovitch \\
\hline & SRS & V & 17 & 0 & 0 & $\begin{array}{l}\text { Moorman (1999, unpubl.), } \\
\text { R. A. Sargent et al. (un- } \\
\text { publ.) }\end{array}$ \\
\hline Total & & & 18 & 0 & 0 & \\
\hline $\begin{array}{l}\text { Blue-gray Gnatcatcher }(P o- \\
\text { lioptila caerulea) }\end{array}$ & PNWR & $\mathrm{C}$ & 2 & 0 & 0 & $\begin{array}{l}\text { Brunjes ( 1998), Raftovitch } \\
\text { (1998) }\end{array}$ \\
\hline \multirow[t]{2}{*}{$\begin{array}{l}\text { Wood Thrush (Hylocichla } \\
\text { mustelina) }\end{array}$} & PNWR & $\mathrm{C}$ & 143 & 2 & I. 4 & $\begin{array}{l}\text { Brunjes (1998), Lang } \\
\text { ( 1998), Raftovitch (1998), } \\
\text { L. A. Powell (unpubl.) }\end{array}$ \\
\hline & SRS & $\mathrm{c}$ & 26 & 0 & 0 & Sargent et al. (2003) \\
\hline Total & & & 169 & 2 & 1.2 & \\
\hline \multirow{3}{*}{$\begin{array}{l}\text { Prairie Warbler (Dendroica } \\
\text { discolor) }\end{array}$} & FBMR & $\mathrm{C}$ & 76 & 16 & 21.0 & Howell ( 199X) \\
\hline & PNWR & $C^{\prime}$ & I 07 & 9 & $x .4$ & $\begin{array}{l}\text { Brunjes ( 1998), Raftovitch } \\
\text { ( 1998) }\end{array}$ \\
\hline & SRS & $\mathrm{U}$ & 8 & 1 & 12.5 & CEM (unpubl.) \\
\hline Total & & & 191 & 26 & 13.6 & \\
\hline $\begin{array}{l}\text { Swainson's Warbler (Lim- } \\
\text { nothlypis swainsonii) }\end{array}$ & SRS & $\mathrm{R}$ & 6 & 0 & 0 & $\begin{array}{l}\text { Moorman (1999), R. A. } \\
\text { Sargent et al. (unpubl.) }\end{array}$ \\
\hline $\begin{array}{l}\text { Ovenbird (Seiurus aurocapil- } \\
\text { lus })\end{array}$ & SRS & $\mathrm{R}$ & 11 & 0 & 0 & $\begin{array}{l}\text { P. J. Champlin and JCK } \\
\text { (unpubl.) }\end{array}$ \\
\hline $\begin{array}{l}\text { Kentucky Warbler (Oporor- } \\
\text { nis formosus) }\end{array}$ & SRS & U & 33 & 0 & 0 & $\begin{array}{l}\text { Sargent et al. ( 1997), Moor } \\
\text { man (1999) }\end{array}$ \\
\hline $\begin{array}{l}\text { Common Yellowthroat } \\
\text { (Geothlypis trichas) }\end{array}$ & SRS & $\mathrm{c}$ & 7 & 0 & 0 & $\begin{array}{l}\text { Moorman ( } 1999) \text {, R. A. } \\
\text { Sargent et al. (unpubl.) }\end{array}$ \\
\hline $\begin{array}{l}\text { Hooded Warbler ( Wilsonia } \\
\text { citrina) }\end{array}$ & SRS & $\mathrm{U}$ & 132 & 19 & 14.4 & $\begin{array}{l}\text { Sargent et al. (1997), Moor- } \\
\text { man et al. (2002) }\end{array}$ \\
\hline \multirow{4}{*}{$\begin{array}{l}\text { Yellow-breasted Chat (Icteria } \\
\text { virens) }\end{array}$} & FBMR & $\mathrm{V}$ & 46 & 8 & 17.4 & Howell ( 199X) \\
\hline & PNWR & $\mathrm{V}$ & 30 & 0 & 0 & $\begin{array}{l}\text { Brunjes (1998), Raftovitch } \\
\text { (1998) }\end{array}$ \\
\hline & SRS & $\mathrm{C}$ & 2 & 0 & 0 & CEM (unpubl.) \\
\hline & JISC & $\mathrm{V}$ & 35 & 13 & 37. $I$ & Whitehead et al. (2000) \\
\hline Total & & & 113 & 21 & I X.6 & \\
\hline $\begin{array}{l}\text { Summer 'Tanager (Piranga } \\
\text { rubra) }\end{array}$ & PNWR & $\mathrm{C}$ & 16 & 1 & 6.3 & $\begin{array}{l}\text { Brunjes ( 1998), Raftovitch } \\
(199 X)\end{array}$ \\
\hline
\end{tabular}


TABLE 2. Continued

\begin{tabular}{|c|c|c|c|c|c|c|}
\hline Species & Sire & $\begin{array}{c}\text { Relative } \\
\text { abundance }\end{array}$ & $\begin{array}{l}\text { Number } \\
\text { of nests }\end{array}$ & $\begin{array}{c}\text { Number } \\
\text { parasitized }\end{array}$ & Percent & Source \\
\hline \multirow{4}{*}{$\begin{array}{l}\text { Northern Cardinal (Cardinal } \\
\text { is cardinalis) }\end{array}$} & FBMR & A & 31 & 1 & 3.2 & Howell ( $199 X)$ \\
\hline & PNWR & A & 49 & 0 & 0 & $\begin{array}{l}\text { Brunjes (1998), Raftovitch } \\
\quad \text { (1998) }\end{array}$ \\
\hline & SRS & A & 59 & 0 & 0 & $\begin{array}{l}\text { Moot-man (1 999), R. A. } \\
\text { Sargent et al. (unpubl.) }\end{array}$ \\
\hline & JISC & $\mathrm{A}$ & 92 & 5 & 5.4 & Whitehead et al. (2000) \\
\hline Total & & & 231 & 6 & 2.6 & \\
\hline \multirow{4}{*}{$\begin{array}{l}\text { Indigo Bunting (Passerina } \\
\text { cyanea) }\end{array}$} & FBMR & V & 54 & 12 & 22.2 & Howell ( 199X) \\
\hline & PNWR & $\mathrm{V}$ & 22 & 3 & 13.6 & $\begin{array}{l}\text { Brunjes (1 99X), Raftovitch } \\
\text { (199X) }\end{array}$ \\
\hline & SRS & $\mathrm{V}$ & II & 0 & 0 & $\begin{array}{l}\text { Moorman (1999, unpubl.), } \\
\text { R. A. Sargent et al. (un- } \\
\text { publ.) }\end{array}$ \\
\hline & JISC & V & 22 & 3 & 13.6 & Whitehead et al. (2000) \\
\hline Total & & & 109 & 18 & 16.5 & \\
\hline $\begin{array}{l}\text { Painted Bunting (Passerina } \\
\text { ciris) }\end{array}$ & JISC & $\mathrm{C}$ & 17 & 6 & 35.3 & Whitehead et al. (2000) \\
\hline \multirow[t]{3}{*}{$\begin{array}{l}\text { Blue Grosbeak (Guiraca ca- } \\
\text { erulea) }\end{array}$} & PNWR & $\mathrm{C}$ & 5 & 0 & 0 & $\begin{array}{l}\text { Brunjes (1998), Raftovitch } \\
(199 \mathrm{X})\end{array}$ \\
\hline & SRS & $\mathrm{V}$ & 5 & 0 & 0 & $\begin{array}{l}\text { CEM (unpubl.), R. A. Sar- } \\
\text { gent et al. (unpubl.) }\end{array}$ \\
\hline & JISC & C & 22 & 6 & 27.3 & Whitehead et al. (2000) \\
\hline Total & & & 32 & 6 & 18.8 & \\
\hline \multirow{3}{*}{$\begin{array}{l}\text { Eastern Towhee (Pipilo ery- } \\
\text { throphthalmus) }\end{array}$} & FBMR & $\mathrm{V}$ & 44 & 1 & 2.2 & Howell (1 99X) \\
\hline & PNWR & $\mathrm{V}$ & 53 & I & I.9 & $\begin{array}{c}\text { Brunjes (199X), Raftovitch } \\
(1998)\end{array}$ \\
\hline & SRS & V & 12 & 2 & 16.7 & $\begin{array}{l}\text { Krementz and Powell } \\
(2000), \text { CEM (unpubl.) }\end{array}$ \\
\hline Total & & & I 09 & 4 & 3.7 & \\
\hline $\begin{array}{l}\text { Red-winged Blackbird (Age- } \\
\text { laiks phoeniceus) }\end{array}$ & $\mathrm{JISC}$ & $\mathrm{V}$ & 73 & 2 & 2.7 & Whitehead et al. (2000) \\
\hline $\begin{array}{l}\text { Orchard Oriole (Icterus spu- } \\
\text { rious) }\end{array}$ & PNWR & $\mathrm{U}$ & 1 & 0 & 0 & $\begin{array}{l}\text { Brunjes (199X), Raftovitch } \\
\qquad(199 X)\end{array}$ \\
\hline \multirow{3}{*}{$\begin{array}{l}\text { Bachman's Sparrow (Aimo- } \\
\text { phila aestivalis) }\end{array}$} & FBMR & $\mathrm{R}$ & 13 & 0 & 0 & Howell ( 199X) \\
\hline & PNWR & $\mathrm{R}$ & 2 & 0 & 0 & $\begin{array}{l}\text { Brunjes ( 1998), Raftovitch } \\
\quad(199 \mathrm{X})\end{array}$ \\
\hline & SRS & $\mathrm{U}$ & 41 & 0 & 0 & Stobcr and Krementz (2000) \\
\hline Total & & & 56 & 0 & 0 & \\
\hline \multirow[t]{2}{*}{$\begin{array}{l}\text { Field Sparrow (Spizella pus- } \\
\quad \text { illa) }\end{array}$} & PNWR & $\mathrm{C}$ & 9 & 0 & 0 & $\begin{array}{l}\text { Brunjes ( 1998), Raftovitch } \\
\text { (1998) }\end{array}$ \\
\hline & SRS & $\mathrm{C}$ & 1 & 0 & 0 & CEM (unpubl.) \\
\hline Total & & & 10 & 0 & 0 & \\
\hline Total (all species) & & & 1,372 & 113 & $X .2$ & \\
\hline Total (parasitized species) & & & 1,212 & 113 & 9.3 & \\
\hline
\end{tabular}

Relative abundance indexed by number of detections per Breeding Bird Strvey route: $\mathrm{R}=\mathrm{rare}(\leq 1)$; $=$ uncommon $(2-3)$ : $\mathrm{C}=\mathrm{common}(4-10)$ : $V=$ very common $(11-30)$; A - abundant $(31-100)$; from distribution maps provided by Sauer ot al. (2003).

nesting species were not. Of 105 ground nests from four species (Ovenbird, Seiurus aurocapillus; Kentucky Warbler; Common Yellowthroat, Geothlypis trichas; and Bachman's
Sparrow, Aimophila aestivalis), none were parasitized. Although cowbirds parasitize these species preferentially in other portions of their range (Hahn and Hatfield 2000), ap- 
parently ground-nesting birds are not important cowbird hosts in the southern Atlantic Coastal Plain and Piedmont.

Even among the frequent hosts, overall parasitism rates were low relative to those reported from other regions. Painted Buntings suffered the highest parasitism rate $(35.3 \%)$, but this rate was based on a moderate sample size, and all nests were from the same site (James Island). Among the remaining frequent host species, overall parasitism rates were $<20 \%$, ranging from $11-19 \%$. In contrast, Hooded Warblers have been reported to experience $45 \%, 62 \%$, and $75 \%$ parasitism in Ontario, Pennsylvania, and Illinois, respectively (Evans Ogden and Stutchbury 1994). Similarly, White-eyed Vireos reportedly experienced $40 \%$ (6 of 15), 48\% (23 of 47), and $83 \%$ (10 of 12) parasitism in Louisiana (Goertz 1977), Virginia (Hopp et al. 1995), and Illinois (Graber et al. 1985), respectively.

The impact of brood parasitism on the seasonal fecundity of hosts at the levels reported here apparently is minimal. Although parasitism reduced the clutch size of Painted Buntings by approximately one egg, Whitehead et al. (2000) concluded that it did not affect the seasonal fecundity of the species, based on application of the seasonal fecundity model of Pease and Grzybowski (1995). Similarly, Moorman et al. (2002) concluded that the effect of parasitism on Hooded Warbler nesting success was minimal. Whitchead ct al. (2000) felt that in their study, low parasitism intensity (i.e., number of cowbird eggs per nest), double brooding by most hosts, and the ability of the hosts to raise cowbird young with their own, ameliorated the impacts of brood parasitism on seasonal fecundity. Of the studies summarized here, only Whitehead ct al. (2000) reported the extent of double brooding. All six species they examined attempted two broods per year, except Yellow-breasted Chats. In several of the reported studies low parasitism intensity was observed; the number of cowbird eggs per parasitized nest was only slightly greater than one (I .0, Raftovitch 1998; 1 .0, R. A. Sargent et al. unpubl. data; 1. 1, CEM unpubl. data; 1.2, Sargent et al. 1997). Likewise, two of the reported studies mentioned that most nests that fledged cowbird young also fedged host young (Howell 1998, Moorman et al. 2002). This evidence, coupled with parasitism rates below 35\% (i.e., that of Painted Buntings), suggests that the conclusions of Whitehead et al. (2000) regarding the lack of an impact of parasitism on seasonal fecundity may be true for most host populations in the southern Atlantic Coastal Plain and Piedmont.

Wiedenfeld (2000) suggested that it is probably not necessary to focus cowbird research in the southeastern Coastal Plain, though he believed monitoring of cowbird population levels was warranted. We agree that brood parasitism does not appear to present an immediate threat to the stability of most host populations in the region. However, we suggest that further research is needed on certain aspects of cowbird parasitism in the Southeast. For example, impacts on the seasonal fecundity of single-brooded species in the region (e.g., Yellow-breasted Chats) are poorly understood. Also, further study is warranted on species whose southeastern populations are considered sensitive, such as Painted Buntings, Swainson's Warblers (Limnothlypis swainsonii), and Black-throated Green Warblers (Dendroica virens; Hunter et al. 2001). Finally, additional information is needed from southeastern landscapes fragmented and dominated by suburban and agricultural habitat, where cowbird abundance may be greater than in the study areas reported here. Parasitism rates at James Island were slightly higher than at the other sites. James Island was converted from a forest and agricultural landscape to a developed landscape since the mid-1980s. As other portions of the Southeast undergo a similar process, the effect of such transition on cowbird parasitism dynamics warrants careful attention.

\section{ACKNOWLEDGMENTS}

We thank the following for graciously sharing and discussing their data: J. H. Brunjes, P. Champlin, M. A. Howell, D. Krementz, J. Lang, L. Powell, R. Raftovitch, R. Sargent, J. Stober, and M. A. Whitehead. D. Lanham and J. Tewksbury reviewed the manuscript. JCK was supported by the U.S. Dept. of Energy, Savannah River Operations Office, through the U.S. Forest Service Savannah River under Interagency Agreement DE-IA09-00SR22 $1 \mathrm{XX}$ and by the Southern Research Station. CEM was supported by North Carolina Stare Univ. 


\section{LITERATURE CITED}

BLAKE, J. I. In press. Silviculture and harvesting activities. In Ecology and management of a forested landscape: SO years of environmental stewardship on the Savannah River Site (J. C. Kilgo and J. 1. Blake, Eds.). Hancock House Publishers, Blaine, Washington.

Brittingham, M. C. AND S. A. TEMPle, 1996. Vegetation around parasitized and non-parasitized nests within deciduous forest. J. Field Ornithol. 67:406413.

BRUNJES, J. H. 199X. The effects of prescribed winter burning on avian communities in mature pine habitats. M.Sc. thesis, Univ. of Georgia, Athens.

Burhans, D. E. 1997. Habitat and microhabitat features associated with cowbird parasitism in two forest edge cowbird hosts. Condor 99:866-872.

Cruz, A., J. W. Prather, W. Post. and J. W. Whley. 2000. The spread of Shiny and Brown-headed cowbirds into the Florida region. Pp. 47-57 in Ecology and management of cowbirds and their hosts (J. N. M. Smith, T, L. Cook. S. I. Rothstein, S. K. Robinson, and S. G. Sealy, Eds.). Univ. of Texas Press, Austin.

Evans Ogden, L. J. And B. J. Stutchbury. 1994. Hooded Warbler (Wilsonia citrina). No. 110 in The birds of North America (A. Poole and F. Gill, Eds.). Academy of Natural Sciences, Philadelphia, Pennsylvania. and the American Ornithologists' Union, Washington, D.C.

FrIEDMANN, H. 1963. Host relations of the parasitic cowbirds. U. S. Nat. Mus. Bulletin 233:1-276.

Friedmann, H. AND L. F. KIFF. 1985. The parasitic cowbirds and their hosts. Proc. Western Found. Vert. Zool. 2:226-304.

Goertz, J. W. 1977. Additional records of Brownheaded Cowbird nest parasitism in Louisiana. Auk 94:386-389.

Graber, J. W., R. R. Graber, and E. L. Kirk. 1985. Illinois birds: vireos. Illinois Natural History Survey, Champaign.

Hahn, D. C. AND J. S. Hatfield. 2000. Host selection in the forest interior: cowbirds target ground-nesting species. Pp. 120-127 in Ecology and management of cowbirds and their hosts (J. N. M. Smith, T. L. Cook, S. I. Rothstein, S. K. Robinson, and S. G. Sealy, Eds.). Univ. of Texas Press, Austin.

hoover, J. P. and M. C. Brittingham. 1993. Regional variation in cowbird parasitism of Wood Thrushes. Wilson Bull. 105:228-238.

Hopp, S. L., A. KRBY, AND C. L. BoONE. 1995. Whiteeyed Vireo (Vireo griseus). No. 168 in The birds of North America (A. Poole and F. Gill, Eds.). Academy of Natural Sciences, Philadelphia, Pennsylvania, and the American Ornithologists' Union. Washington, D.C.

Howell, M. A. 1998. Avian nesting success and nestsite selection in mature pine stands maintained by prescribed fire in Georgia. M.Sc. thesis, Univ. of Georgia, Athens.
Hunter, W. C., L. H. Peoples, and J. A. Collazo. 2001. Bird conservation plan for South Atlantic Coastal Plain. Partners In Flight, Atlanta, Georgia (http://www.blm.gov/wildlife/plan/pl_03_10.pdf).

Krementz, D. G. AND L. A. POWEll, 2000. Breeding season demography and movements of Eastern Towhees at the Savannah River Site, South Carolina. Wilson Bull. 1 12:243-248.

LANG, J. D. 199X. Effects of thinning and prescribed burning in pine habitat on nesting success, fledgling dispersal, and habitat use by Wood Thrushes. M.Sc. thesis, Univ. of Georgia, Athens.

LOWTHER, P. E. 1993. Brown-headed Cowbird (Molothrus ater). No. 47 in The birds of North America (A. Poole and F. Gill, Eds.). Academy of Natural Sciences, Philadelphia, Pennsylvania, and the American Ornithologists' Union, Washington, D.C.

Martin, 'T. E. AND G. R. Geupel. 1993. Nest monitoring plots: methods for locating nests and monitoring success. J. Field Ornithol. 64:507-5 19.

MOORMAN, C. E. 1999. Relationships between artificially created gaps and breeding birds in a southeastern bottomland forest. Ph.D. diss., Clemson Univ., Clemson, South Carolina.

MOORMAN, C. E., D. C. GUYnN, JR., AND J. C. Kilgo. 2002. Hooded Warbler nesting success adjacent to group-selection and clearcut edges in a southeastern bottomland forest. Condor 104:366-377.

Nolan, V., JR. 197X. The ecology and behavior of the Prairie Warbler Dendroica discolor. Ornithol. Monogr: 26: 1-595.

PEASE, C. M. AND J. A. GRzYBOWSk! 1995. Assessing the consequences of brood parasitism and nest predation on seasonal fecundity in passerine birds. Auk 112:343-363.

Potter, E. F. AND G. T. Whtrehurst. 1981 Cowbirds in the Carolinas. Chat 45:57-68.

RAFToVITCH, R. V., JK. 199X. Effects of management for Red-cockaded Woodpeckers on avian communities in mature pine stands in the Georgia Piedmont. M.Sc. thesis, Univ. of Georgia, Athens.

Robinson, S. K., F. R. ThOMpson, III, T. M. DOnOVAN, D. R. Whitehead. AND J . FAaborg. 1995. Regional forest fragmentation and the nesting success of migratory birds. Science 267: 1987- 1990,

RoTh, R. R., M. S. JHNSON, AND T, J. UNDERWOOD, 1996. Wood Thrush (Hylocichla mustelina). No. 246 in The birds of North America (A. Poole and F. Gill, Eds.). Academy of Natural Sciences, Philadelphia, Pennsylvania, and the American Ornithologists' Union, Washington, D.C.

Rothstein, S. I., J. Verner, And E. Stevens. 1984. Radio-tracking confirms a unique diurnal pattern of spatial occurrence in the parasitic Brown-headed Cowbird. Ecology 65:77-88.

Sargent, R. A., J. C. Kilgo, B. R. Chapman, and K. V. Miller. 1997. Nesting success of Kentucky and Hooded warblers in bottomland forests of South Carolina. Wilson Bull. 109:233-238.

Sargent, R. A., J. C. Kllgo, B. R. Chapman, and K. 
V. Miller. 2003. Nesting ecology of Wood Thrush (Turdidae: Passeriformes) in hardwood forests of South Carolina. Southeast. Nat. 2:2 17222.

Sauer, J. R., J. E. Hnes, and J. Fallon. 2003. The North American Breeding Bird Survey, results and analysis 1966-2002, ver. 2003.1. USGS Patuxent Wildlife Research Center, Laurel, Mary1 a n d (http://www.mbr-pwrc.usgs.gov/bbs/bbs. html).

SCHMIDT, K. A. AND C. J. Whelan. 1999. The relative impacts of nest predation and brood parasitism on seasonal fecundity in songbirds. Conserv. Biol. $13: 46-57$

STOBER, J. M. AND D. G. KREMENTZ. 2000. Survival and reproductive biology of the Bachman's Sparrow. Proc. Southeast. Assoc. Fish and Wildl. Agencies 54:383-390.

THOMPSON, F. R., III. 1994. Temporal and spatial patterns of breeding Brown-headed Cowbirds in the midwestern United States. Auk 1 11:979-990.
Trani, M. K., R. T. Brooks, T. L. Schmidt, V. A. RUDIS, AND C. M. GABBARD. 2001 Patterns and trends of early successional forests in the eastern United States. Wild. Soc. Bull. 29:413-424.

White, D. H., B. R. Chapman, J. H. Brunjes, IV. R. V. Raftovitch, JR., AND J. T. SEgINAK. 1999. Abundance and reproduction of songbirds in burned and unburned pine forests of the Georgia Piedmont. J. Field Ornithol. 70:414-424.

Whitehead, M. A., S. H. SChwertzer, AND W. Post. 2000. Impact of brood parasitism on nest survival parameters and seasonal fecundity of six songbird species in southeastern old-field habitat. Condor $102 ; 946-950$.

WIEDENFELD, D. A. 2000. Cowbird population changes and their relationship to changes in some host species. Pp. 35-46 in Ecology and management of cowbirds and their hosts (J. N. M. Smith. T. L. Cook, S. I. Rothstein, S. K. Robinson, and S. G. Sealy, Eds.). Univ. of Texas Press, Austin. 